Scientific paper

\title{
Electro-catalytic Oxidation of Catechol at Poly(1-amino-9,10-anthraquinone)-SDS Composite Film
}

\author{
Hossein Nikoofard* and Malihe Solbi \\ Faculty of Chemistry, Shahrood University of Technology, Shahrood 36199-95161, Iran \\ * Corresponding author: E-mail: hnikoofard@ shahroodut.ac.ir \\ Tel.: +98233239 5441; Fax: +982332395441
}

Received: 18-01-2016

\begin{abstract}
An electro-chemically active composite film containing the environmentally friendly surfactant sodium dodecyl sulfate (SDS) and poly(1-amino-9,10-anthraquinone) (PAAQ) is used as an electron transfer mediator in the electro-chemical oxidation of catechol. Compared with the bare platinum (Pt) electrode, the Pt/PAAQ-SDS modified electrode remarkably lowers the anodic peak potential of catechol, and increases the peak currents. The results obtained indicate that the activation energy for the electro-chemical oxidation of catechol at the polymer film is low $\left(7.05 \mathrm{~kJ} \mathrm{~mol}^{-1}\right)$. The influence of the operational conditions on the response current of the catechol sensor is also investigated. Studying the surface morphology of the modified electrode reveals a more porous structure for it due to the incorporation of the anionic surfactant on the PAAQ film. The modified electrode displays a linear response in the concentration range of 0.01-8.0 m$\mathrm{M}$ for catechol. A lower detection limit was obtained to be $2.60 \mu \mathrm{M}$. The ability of the modified electrode is also examined for the electro-chemical detection of hydroquinone (HQ) with simplicity.
\end{abstract}

Keywords: Electro-catalytic oxidation; Coated polymeric film; Catechol; Poly(1-amino-9,10-anthraquinone) (PAAQ); Sodium dodecyl sulfate (SDS).

\section{Introduction}

Catechol (1,2-dihydroxybenzene) is one of the most important phenolic compounds occurring naturally in the environment. Catechol-based compounds are formed during the biological degradation processes, and are used in a wide range of industrial applications. ${ }^{1,2}$ In addition, they are of biological importance; for instance, they have anti-oxidation and anti-viral activities and flower stimulating effects and affect the activities of some enzymes. ${ }^{3,4}$ On the other hand, they are highly toxic to the humans, animals, plants, and aquatic life when present above certain concentration limits. ${ }^{5-7}$ Several analytical techniques such as spectrophotometry ${ }^{8}$ and high pressure liquid chromatography (HPLC) ${ }^{9}$ have been used for the determination of catechol and its derivatives. However, these methods are usually costly, complicated, and time-consuming procedures for routine analyses. The electro-chemical techniques are promising approaches due to their sensitivity, rapidity, and simplicity.

The direct electro-chemical determination of catechol at common electrodes shows important disadvanta- ges such as high over-potential, poor selectivity, irreversibility, and electrode fouling. ${ }^{10,11}$ These difficulties can be minimized using an electro-chemically modified electrode, which can minimize or overcome most of the above-mentioned problems. Modified electrodes contain redox mediators, which have the ability to improve the rate of electron transfer from the substrate to the electrode. ${ }^{12,13}$ It has been found that many redox materials have been used as the electron transfer mediators for the electro-chemical oxidation of catechol. These modified electrodes contain various quinone derivatives, nano-particles, and some conducting polymers. ${ }^{14-19}$ In this regard, electro-polymerization is a simple and powerful method that can be implemented in targeting a selective modification of different types of substrates with the desired materials. Poly(1-amino-9,10-anthraquinone) (PAAQ), a conducting polymer, has received a considerable attention due to its excellent properties such as environmental stability, good electro-activity, high electrical conductivity, powerful specific electro-capacity, fast reversible redox ability, and its use as an electrode for biosensors. ${ }^{20-24}$ 
Recently, we have reported a detailed study of the preparation of the PAAQ film-coated electrodes in the presence of multi-walled carbon nanotubes (MWCNTs) on a glassy carbon (GC) electrode in a non-aqueous medium. ${ }^{25}$ We have also synthesized a new PAAQ film via the electro-polymerization of 1-amino-9,10-anthraquinone (AAQ) in the micelle solutions of sodium dodecyl sulfate (SDS). ${ }^{26}$ These new composite films show a good electro-activity in a buffer solution. This may be attributed to the reversible redox reactions of a functional amino group present in the PAAQ chains. The reversible redox reactions are accompanied by proton exchange between the polymer and the buffer solution, which improves the $\mathrm{pH}$-dependence of the electro-chemical activity of the polymer film. A preliminary study has shown that the PAAQ-SDS film can be used as an electron transfer mediator for the electro-catalytic oxidation of catechol. ${ }^{26}$ Thus the use of the PAAQ-SDS composite film as an electro-chemical sensor might be of great interest for analytical applications. In the present work, the PAAQ-SDS composite film, as a modified electrode, was fabricated by means of the electro-polymerization of the AAQ monomer in a micelle solution of SDS. The electro-chemical behavior of catechol at the PAAQ-SDS modified electrode was investigated by cyclic voltammetry $(\mathrm{CV})$. A detailed description was also presented to show the influence of the operational conditions on the sensor activity. Finally, the ability of the PAAQ-SDS sensor to detect the hydroquinone (HQ) concentration, as a catechol isomer, was examined.

\section{Materials and Method}

\section{1. Reagents}

All the chemicals used including AAQ (supplied from Sigma-Aldrich), sulfuric acid (from Merck), catechol (from Merck), HQ (from Merck), SDS (from SigmaAldrich), and phosphate-buffered saline (from Sigma-Aldrich) were of analytical grade, and were used as received, without further purification. All solutions were prepared using triply distilled water. All experiments were carried out at room temperature, unless otherwise stated.

\section{2. Apparatus}

A conventional three-electrode cell was used with a disk electrode (Pt, $\mathrm{Au}$, and $\mathrm{GC}$ electrodes) as the working electrode, a saturated calomel electrode (SCE) as the reference electrode, and a Pt wire as the counter-electrode. The working electrodes had a geometrical surface area of $0.07 \mathrm{~cm}^{2}$. Before each experiment, the working electrodes were polished mechanically with alumina powder of 1.0$\mathrm{mm}$ diameter, washed, and then rubbed against a smooth cloth. All the electro-chemical measurements were performed using a BPE potentiostat-galvanostat (Iran) equipped with a PC and an electro-chemical setup that was controlled with a software. All the reported potentials were referred to SCE. The scanning electron microscopy (SEM) images were taken using a Hitachi instrument (S-4160) at various magnifications.

\section{3. Preparation of PAAQ-SDS Modified Electrodes}

The conventional PAAQ-SDS films were synthesized on a Pt working electrode (unless otherwise stated) using the $\mathrm{CV}$ method in an aqueous solution containing the AAQ monomer $(4 \mathrm{mM})$, SDS surfactant $(0.4 \mathrm{mM})$, and $\mathrm{H}_{2} \mathrm{SO}_{4}(6.0 \mathrm{M})$ at a scan rate of $50 \mathrm{mV} \mathrm{s}^{-1}$ over a sweeping potential range of $0.0-1.3 \mathrm{~V}$. It should be noted that CMC of SDS in $\mathrm{H}_{2} \mathrm{SO}_{4}(0.5 \mathrm{M})$ has been reported to be $0.07 \mathrm{mM},{ }^{27}$ which decreases on a further increase in an acidic electrolyte. The thickness of the polymer film was dependent on the number of deposited cycles. ${ }^{17}$ The cycle number of 12 was preferred for the preparation of the PAAQ-SDS modified electrode. The characterization of the PAAQ-SDS composite film by the potentio-state, potentio-dynamic, and SEM techniques have been described elsewhere. ${ }^{26}$

\section{Results and Discussion}

\section{1. Electro-catalytic Response of Catechol at PAAQ-SDS Modified Electrode}

Figure 1 shows the electro-chemical behavior of the Pt/PAAQ-SDS modified electrode and the bare Pt electrode toward the electro-oxidation of catechol $(2.0 \mathrm{mM})$ in a phosphate buffer solution $(\mathrm{pH} 5.0)$ at a scan rate $(v)$ of $50 \mathrm{mV} \mathrm{s}^{-1}$ over a potential range of $0.1-0.8 \mathrm{~V}$. The CV$\mathrm{s}$ presented in Figure 1 reveal that in the case of the Pt/PAAQ-SDS modified electrode, the oxidation and reduction peaks for catechol were observed at 0.50 and $0.34 \mathrm{~V}$, respectively. The separation between the anodic and cathodic peak potentials $\left(\Delta E_{\mathrm{p}}\right)$ were determined to be 0.16 and $0.32 \mathrm{~V}$ at the Pt/PAAQ-SDS modified electrode and the bare Pt electrode, respectively. The redox reaction of catechol showed a good electro-activity at the PAAQ-SDS composite film. According to the background response (curve $\mathrm{c}$ in Figure 1), CV for the modified electrode showed no peak current in the catecholfree solution at $\mathrm{pH} 5.0$ over the potential range of $0.1-0.8$ $\mathrm{V}$. It has been found that an acidic concentration of $4.0 \mathrm{M}$ or higher is essential to observe the peak currents for the PAAQ films ${ }^{17}$ In comparison with curve b in Figure 1, the oxidation peak current for catechol at the Pt/PAAQSDS modified electrode was higher than that at the bare Pt electrode. However, a shift toward lower potential values was observed for the electro-oxidation potential of catechol at the Pt/PAAQ-SDS modified electrode. The re- 


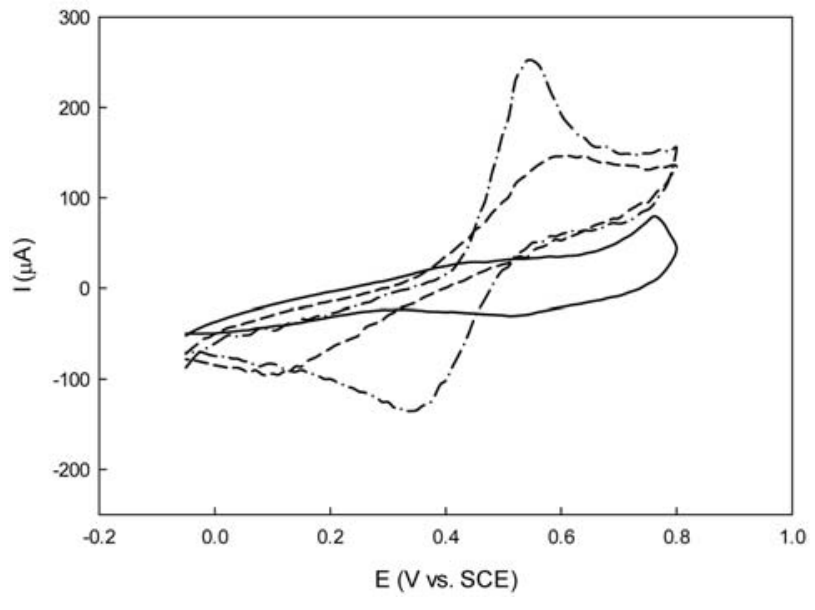

Figure 1. CVs for electro-chemical oxidation of catechol (2.0 mM) in a phosphate buffer solution ( $\mathrm{pH}$ 3.0) at Pt/PAAQ-SDS modified electrode (dash-dot) and bare Pt electrode (dash-dash). CV for blank phosphate buffer solution ( $\mathrm{pH} 3.0$ ) at modified electrode (solid) has been shown for comparison.
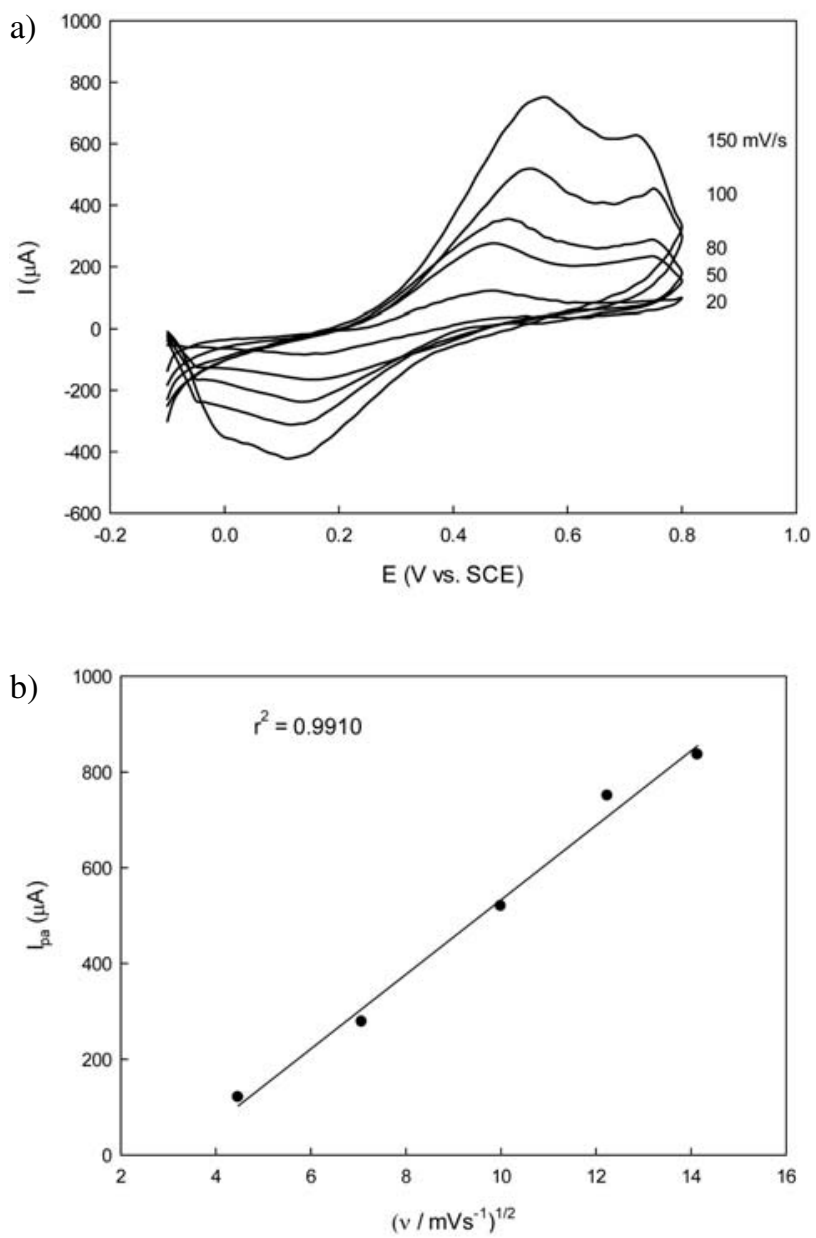

Figure 2. (a) Effect of scan rate on CV for Pt/PAAQ-SDS modified electrode in a phosphate buffer solution at $\mathrm{pH} 5.0$ containing 2.0 $\mathrm{mM}$ of catechol at 20,50,80,100,150, and $200 \mathrm{mV} \mathrm{s}^{-1}$. (b) Linear behavior of $I_{\mathrm{pa}}$ as a function of scan rate for electro-chemical response of polymer film. sults obtained indicated that the modified electrode had an electro-catalytic activity for catechol oxidation in a phosphate buffer solution at $\mathrm{pH}$ 5.0.

The effect of the scan rate on the redox reaction of catechol was also studied. Figure 2(A) shows the CVs for catechol at the Pt/PAAQ-SDS modified electrode at different scan rates in a phosphate buffer solution at $\mathrm{pH} 5.0$ containing $2.0 \mathrm{mM}$ of catechol. As one can see in this figure, the oxidation peak current increased as the scan rate increased, and, in addition, the oxidation peak potential was observed to shift slightly to a more positive value with an increase in the scan rate. This indicates that the modified electrode has a good electro-chemical activity and a fast charge transfer at $\mathrm{pH}$ 5.0. The oxidation peak currents exhibited a linear relation with the square root of the scan rate $\left(v^{1 / 2}\right)$ with the correlation coefficient linear $r^{2}$ $=0.9910$ (Figure 2B). This means that the oxidation reaction of catechol at the Pt/PAAQ-SDS modified electrode is a diffusion-controlled process, which is necessary for quantitative measurements. The results obtained indicate that the PAAQ-SDS sensor exhibits a good sensitivity and fast response, and that the coated polymer functions as the electron transfer mediator between the substrate surface and the analyte.

\section{2. Effect of Thickness of Polymer Film on Response of Modified Electrode}

It is known that the thickness of the PAAQ-SDS composite films, prepared by $\mathrm{CV}$, is directly dependent on the scan repetition during the electro-polymerization process. ${ }^{17}$ The PAAQ-SDS films were deposited on a Pt substrate in a $6.0 \mathrm{M} \mathrm{H}_{2} \mathrm{SO}_{4}$ solution containing $4.0 \mathrm{mM}$ of the AAQ monomer and $0.4 \mathrm{mM}$ of SDS using cycles ranging from 5 to 25 . After 10 scan repetitions, a relatively adherent golden green film was formed. By increasing the number of cycles (to more than 20), a thicker adherent dark green film was obtained. The effect of the film thickness, corresponding to the number cycles, on the response of catechol was studied. It was found that the electro-catalytic nature of the PAAQ-SDS film was affected by the different number of cycles. Figure 3 displays several CVs for the PAAQ-SDS modified electrodes (prepared at 9, 12, and 15 cycles) toward the electrooxidation of catechol $(2.0 \mathrm{mM})$ in a phosphate buffer solution (pH 5.0) at a scan rate of $50 \mathrm{mV} \mathrm{s}^{-1}$. The results obtained reveal that the anodic peak current increases after increasing the number of cycles to 12 . Then a further increase in the scan repetitions causes the current response to be slightly lowered, with a small positive shift in position. This behavior indicates the activity of the polymer films of certain thickness levels, most probably due to a barrier for the electron transfer in the thick films. Cycle number 12 during the electro-polymerization of the AAQ monomer was selected as the optimum one, and used in the further experiments. 


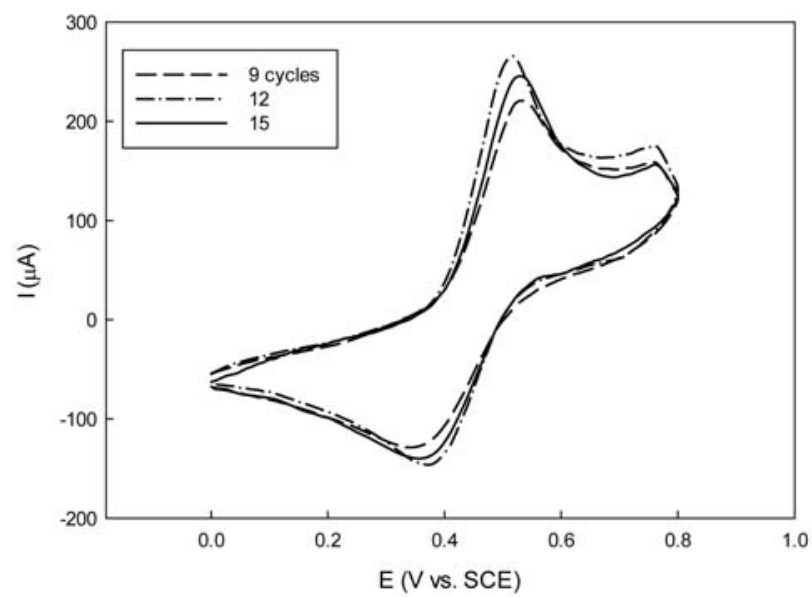

Figure 3. Effect of number of cycles of CVs during electro-polymerization of AAQ monomer (thickness film) on response current of PAAQ-SDS modified electrode in a phosphate buffer solution at pH 5.0 containing $2.0 \mathrm{mM}$ of catechol (several curves: 9, 12, and 15 cycles).

\section{3. Effect of Substrates on Response of Modified Electrodes}

It is known that several substrates including platinum $(\mathrm{Pt})$, gold $(\mathrm{Au})$, glassy carbon $(\mathrm{GC})$, graphite $(\mathrm{C})$, and silver $(\mathrm{Ag})$ can usually be used for the preparation of a coated polymeric film. Under the same operational conditions, the PAAQ-SDS film was deposited on different types of substrates. The results obtained from the CV responses for the different modified electrodes toward catechol $(2.0 \mathrm{mM})$ in a phosphate buffer solution $(\mathrm{pH} 5.0)$ at a scan rate of $50 \mathrm{mV} \mathrm{s}^{-1}$ over the potential range of $0.1-0.8$ $\mathrm{V}$ were tabulated in Table 1. It was found that the response of modified electrode was affected by the substrates. Comparing the results obtained for the $E_{\mathrm{pa}}, \Delta E_{\mathrm{p}}$, and $I_{\mathrm{pc}} / I_{\mathrm{pa}}$ quantities showed that the redox activity of the electrode at the polymer film coated on the Pt and Au electrodes was larger than the one deposited on the GC electrode. This may be explained by the fact that the composite polymer film did not cover the whole surface of the GC electrode. However, the electro-chemical behaviors of the Pt/PAAQ-SDS and Au/PAAQ-SDS films were similar; the former was preferred because its peak current ratio $\left(I_{\mathrm{pc}} / I_{\mathrm{pa}}\right)$ approached unity.

Table 1. Effect of substrates on response of modified electrodes in a phosphate buffer solution at $\mathrm{pH} 5.0$ containing $2.0 \mathrm{mM}$ of catechol.

\begin{tabular}{lccc}
\hline Modified electrodes & $\boldsymbol{E}_{p a}(\mathbf{m V})$ & $\boldsymbol{\Delta} \boldsymbol{E}_{p}(\mathbf{m V})$ & $\boldsymbol{I}_{p c} \boldsymbol{I}_{\boldsymbol{p}}$ \\
\hline Pt/PAAQ-SDS & 5.60 & 0.68 & 0.65 \\
Au/PAAQ-SDS & 5.50 & 0.56 & 0.50 \\
GC/PAAQ-SDS & 6.30 & 2.10 & 0.38 \\
\hline
\end{tabular}

The surface morphology of the PAAQ-SDS ?lm deposited on the Pt electrode was visualized by SEM. The SEM images for the PAAQ-SDS film grown using CV during 12 cycles with a scan rate of $50 \mathrm{mV} \mathrm{s}^{-1}$ in $\mathrm{H}_{2} \mathrm{SO}_{4}(6.0$ $\mathrm{M}$ ) containing $4.0 \mathrm{mM}$ of the AAQ monomer are illustrated in Figure 4 (in different magnifications). These images show the uniform growth of the polymer ? $1 \mathrm{~m}$ on the electrode because all the surfaces were progressively covered by the polymer. The PAAQ-SDS modified polymer shows an open and more porous structure with a distribution of the nano-sized particles on the underlying compact film. This structure should facilitate the diffusion and exchange of the ionic and dopant species during the electro-chemical transformations of the electro-active polymeric film between the reduced and oxidized states.
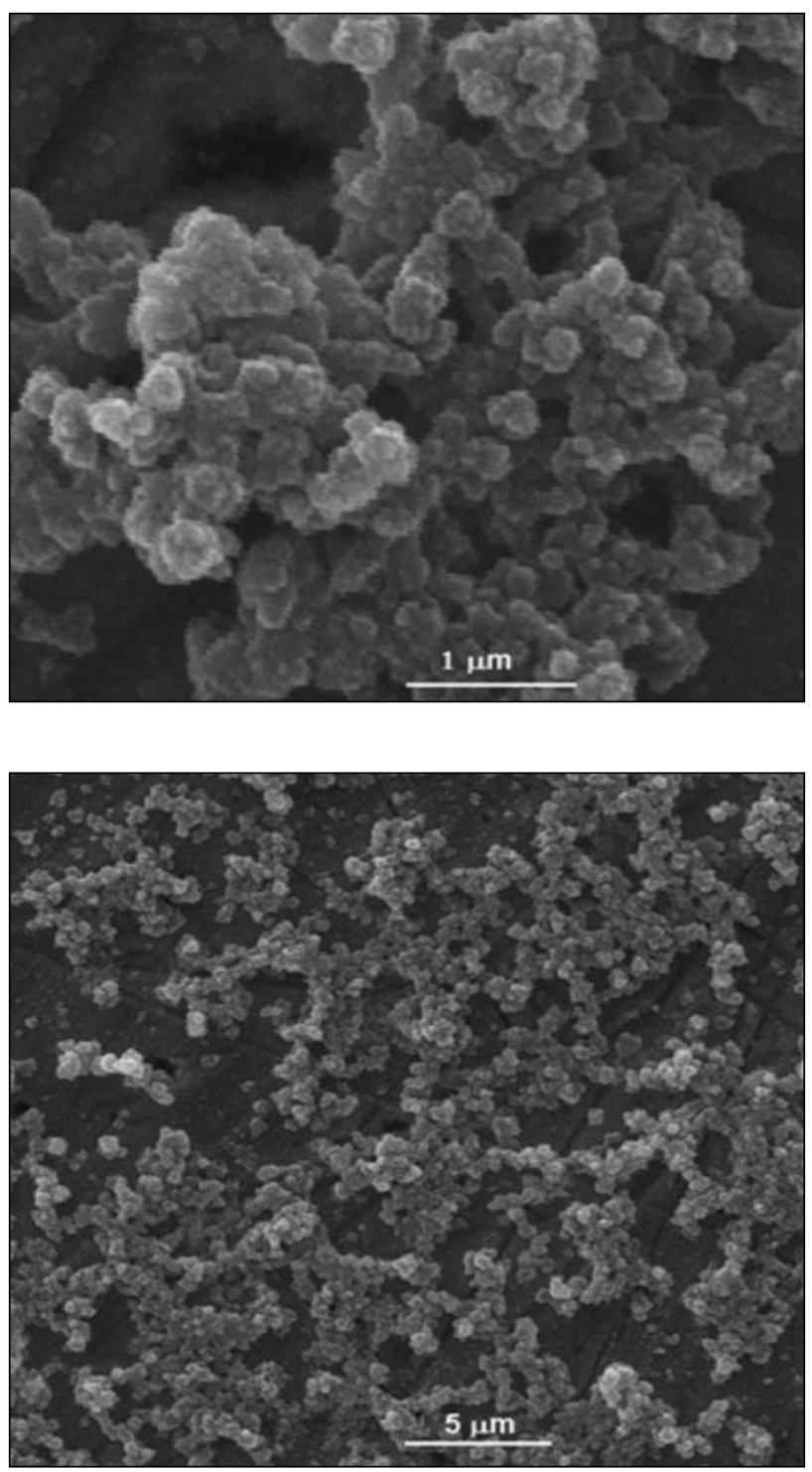

Fig. 4. SEM images for PAAQ-SDS film (in different magnifications). 


\section{4. Effect of $\mathrm{pH}$ and Supporting Electrolyte on Response of Modified Electrode}

The peak current response of the Pt/PAAQ-SDS modified electrode toward oxidation of catechol in different types of supporting electrolytes was evaluated. At the same conditions of $\mathrm{CV}$ measurement, the anodic peak currents for catechol $(2.0 \mathrm{mM})$ at different supporting electrolytes including acetate, phosphate, and citrate (at the constant $\mathrm{pH}$ of 5.0) were tabulated in Table 2. It was found that the response of the Pt/PAAQ-SDS modified electrode in the phosphate solution was higher than that in other supporting electrolyte solutions. Thus the phosphate buffer was selected for further studies.

Table 2. Anodic peak current response of catechol $(2.0 \mathrm{mM})$ in different types of supporting electrolytes at $\mathrm{pH}$ 5.0.

\begin{tabular}{lccc}
\hline Supporting electrolytes & Acetate & Phosphate & Citrate \\
\hline$I_{\mathrm{pa}}(\mu \mathrm{A})$ & 170.0 & 231.0 & 190.3 \\
\hline
\end{tabular}

a)
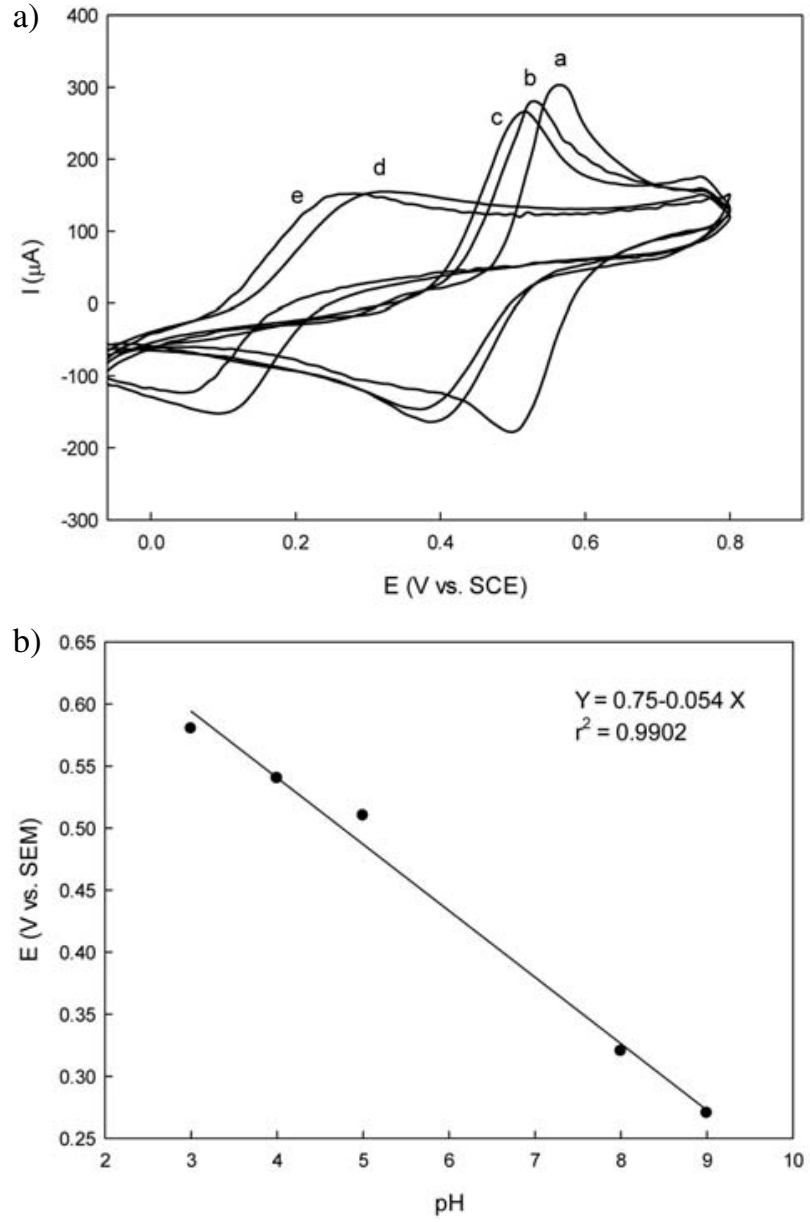

Figure 5. (a) $\mathrm{CVs}$ for Pt/PAAQ-SDS modified electrode in a phosphate buffer solution at different $\mathrm{pH}$ values containing $2.0 \mathrm{mM}$ of catechol; pH: (a) 3, (b) 4, (c) 5, (d) 8, and (e) 9. (b) Linear behavior of anodic peak potential as a function of $\mathrm{pH}$ for electro-chemical response of polymer film.
The influence of the solution $\mathrm{pH}$ on the electro-catalytic oxidation of catechol at the PAAQ-SDS modified electrode was investigated by CV over a range of 3.0-9.0 at the PAAQ-SDS film in a phosphate buffer solution containing $2.0 \mathrm{mM}$ of catechol over a potential range of $0.1-0.8 \mathrm{~V}$ (Figure 5A). According to this figure, the observed $\mathrm{pH}$ dependence seems to be consistent with the oxidation of catechol, as the following equation:

$$
\mathrm{C}_{6} \mathrm{H}_{6} \mathrm{O}_{2} \rightarrow \mathrm{C}_{6} \mathrm{H}_{4} \mathrm{O}_{2}+2 \mathrm{e}^{-}+2 \mathrm{H}^{+}
$$

It can be seen that the anodic peak current for catechol increased with decrease in the $\mathrm{pH}$ of the supporting electrolyte. At a pH value higher than 5.0, the peak currents decreased rapidly with a rise in the $\mathrm{pH}$ from 5.0 to 9.0. In view of the fact that the electro-polymerization potential of catechol decreased with increasing $\mathrm{pH},{ }^{28}$ a solution at $\mathrm{pH} 5.0$ was used in the further experiments. Besides, the relationship between the $\mathrm{pH}$ and the anodic peak potential $\left(E_{\mathrm{pa}}\right)$ was shown in Figure 5(B). It was found that the anodic peak potentials shifted negatively with increase in the $\mathrm{pH}$, indicating that protons took part in the electrode reaction process. The linear behavior of peak potential with the $\mathrm{pH}$ was $E_{\mathrm{pa}}=0.75-0.054 \mathrm{pH}\left(\mathrm{V}, r^{2}=\right.$ 0.9902). The calculated slope $(0.054 \mathrm{~V} / \mathrm{pH})$ can be used to predict the Nerstian value $(0.059 \mathrm{~V} / \mathrm{pH})$ for a two-proton coupled two-electron transfer. ${ }^{29}$

\section{5. Effect of Temperature on Response Current of Modified Electrode}

The relationship between the temperature $(T)$ and the anodic peak current for the Pt/PAAQ-SDS modified electrode in a phosphate buffer solution at $\mathrm{pH} 5.0$ containing $2.0 \mathrm{mM}$ of catechol was studied over a temperature range of $278-328 \mathrm{~K}$. The results obtained revealed that $I_{\mathrm{pa}}$

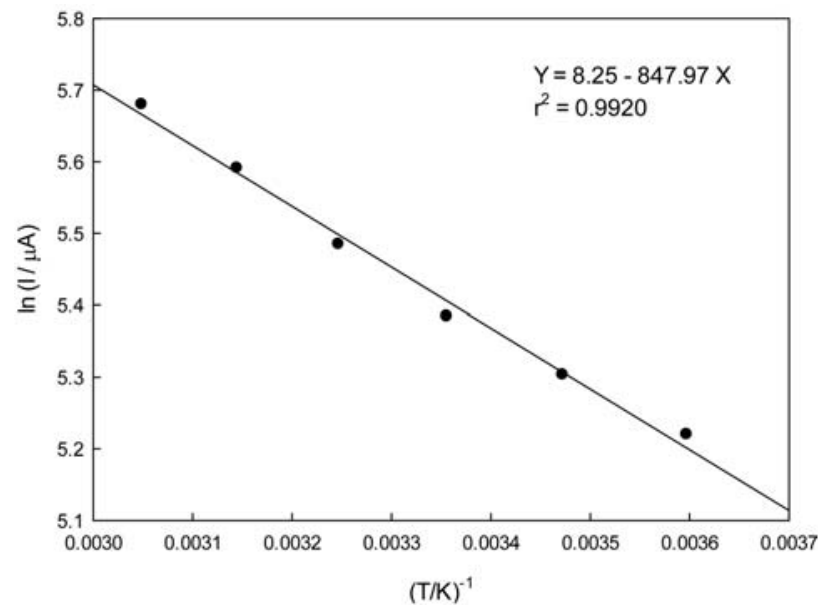

Figure 6. Plot of $\ln \left(I_{\mathrm{pa}}\right) v s . \mathrm{T}^{-1}$ for response anodic peak current of polymer film in a phosphate buffer solution at $\mathrm{pH} 5.0$ containing $2.0 \mathrm{mM}$ of catechol at a scan rate of $50 \mathrm{mV} \mathrm{s}^{-1}$. 
increased with increase in the temperature. In considering the electro-chemical version of the Arrhenius equation, ${ }^{30} \mathrm{a}$ plot of $\ln \left(I_{\mathrm{pa}}\right)$ vs. $\mathrm{T}^{-1}$ gave a straight line, $\mathrm{Y}=8.25-$ 847.97 X $\left(r^{2}=0.9920\right)$, as shown in Figure 6. The observed activation energy $\left(E_{\mathrm{a}}\right)$ for the oxidation of catechol was obtained from the slope of the line; it was $7.05 \mathrm{~kJ}$ $\mathrm{mol}^{-1}$. The results obtained revealed that the observed activation energy was low; this corresponds to the fast electron transfer at the PAAQ-SDS sensor.

\section{6. Electro-analytical Determinations}

Cyclic voltammetry was used for the direct determination of catechol because it showed a well-defined anodic peak current on the Pt/PAAQ-SDS modified electrode. The Pt/PAAQ-SDS modified electrode response was found to be sensitive to a change in the concentration of catechol. Figure 7 shows a change in the response current with the concentration of catechol over a wide range of $0.01-8.0 \mathrm{mM}$ in a phosphate buffer solution (p$H$ 5.0). A linear response of the modified electrode was obtained by plotting the background corrected current as a function of the catechol concentration with a correlation coefficient of 0.9943 . This linear relationship can be used to determine the unknown amounts of catechol in the specified concentration range. According to the inset of Figure 7, an excellent linear behavior $\left(r^{2}=0.9982\right)$ was obtained for the response of the modified electrode over the catechol concentration range of $10-100 \mu \mathrm{M}$, which was similar to those of the biosensors based on immobilized horseradish peroxidase $(10-50 \mu \mathrm{M})^{31}$ and tyrosinase $(1-23 \mu \mathrm{M}){ }^{32}$ Thus this detection range was used to calculate the detection limit. A lower limit of detection (LOD) was calculated using the standard approach of alternative:

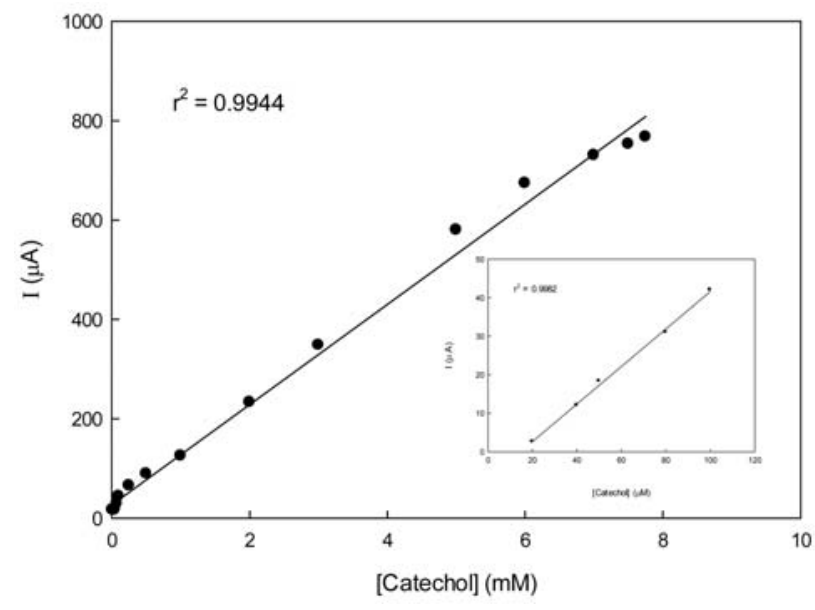

Figure 7. Relationship between response anodic peak current of polymer film and catechol concentration in a phosphate buffer solution $(\mathrm{pH}$ 5.0) at a scan rate of $50 \mathrm{mV} \mathrm{s}^{-1}$. Inset shows calibration curve for voltammetric determination of catechol in concentration range of $10-100 \mu \mathrm{M}$.

$$
\mathrm{OD}=3 * S_{\mathrm{b}} / m
$$

where $S_{\mathrm{b}}$ is the standard deviation of the blank signal, and $m$ is the slope of the calibration curve. ${ }^{33}$ Based on the slope obtained for the calibration curve $(0.52 \mu \mathrm{A} / \mu \mathrm{M})$ and the standard deviation of the blank signal obtained from 10 different runs $(0.45 \mu \mathrm{A}), \mathrm{LOD}$ was found to be 2.60 $\mu \mathrm{M}$ in the specified concentrations. Beside the simplicity of the preparation of the modified electrodes, they have a good operational stability. They could be used several times for 20 days when stored under a noble gas atmosphere at room temperature.

As a preliminary study, the electro-chemical behavior of HQ was also examined on the modified electrode. HQ is a class of polluting chemicals that, when absorbed through the skin and mucous membranes, can cause damage to the lungs, liver, kidneys, and genet-urinary tract in the animals and humans. ${ }^{34-37}$ Figure 8 shows the CVs recorded for the PAAQ-SDS modified electrode and the bare Pt electrode toward the electro-oxidation of HQ (2.0 $\mathrm{mM}$ ) in a phosphate buffer solution at $\mathrm{pH} 5.0$ over the potential range of $0.2-1.0 \mathrm{~V}$. The anodic peak current (and the separation of peak potentials) for the HQ redox reaction were determined to be $223.32 \mu \mathrm{A}(0.49 \mathrm{~V})$ and 174.69 $\mu \mathrm{A}(0.60 \mathrm{~V})$ at the modified and bare Pt electrodes, respectively. It was found that the HQ redox activity at the Pt/PAAQ-SDS modified electrode was higher than that at the bare Pt electrode. This result indicated that the modified electrode also had an electro-catalytic activity for the HQ oxidation. In comparison with the PAAQ-SDS/catechol curve (Figure 1), the rate of charge transfer for the catechol redox reaction was higher than HQ at the PAAQSDS modified electrode.

A linear response was obtained for the modified electrode to the electro-oxidation of HQ over a range of

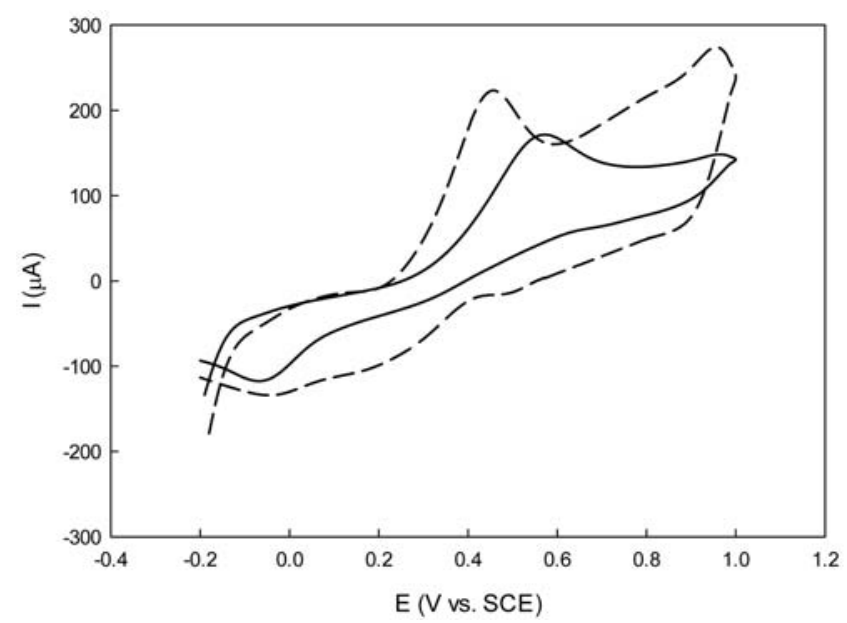

Fig. 8. CVs for electro-chemical oxidation of HQ $(2.0 \mathrm{mM})$ in a phosphate buffer solution ( $\mathrm{pH}$ 5.0) at Pt/PAAQ-SDS modified electrode (dash-dash) and bare Pt electrode (solid). 


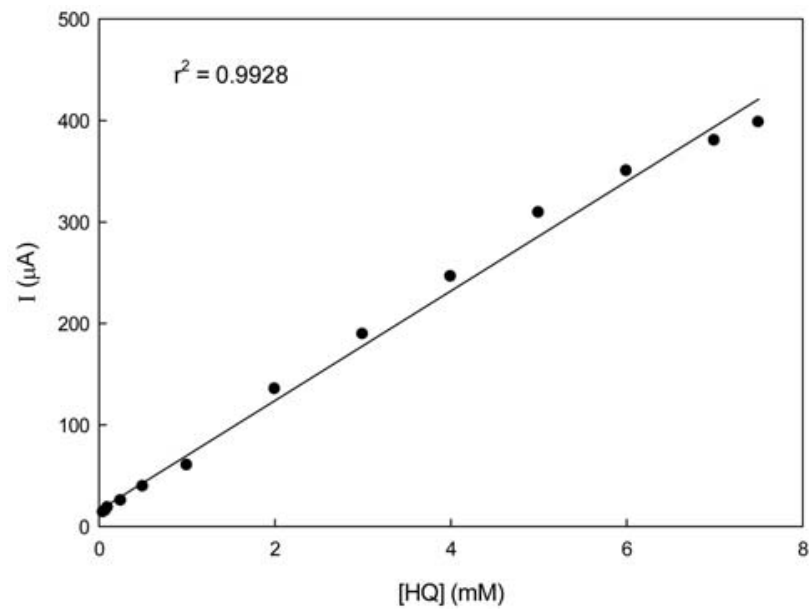

Figure 9. Linear behavior of anodic peak current as a function of concentration for electro-oxidation response of $\mathrm{HQ}$ in a phosphate buffer solution ( $\mathrm{pH}$ 5.0) at Pt/PAAQ-SDS modified electrode.

$0.01-8.0 \mathrm{mM}$ by plotting the background corrected current as a function of the HQ concentration (Figure 9). This linear relationship, $r^{2}=0.9928$, can be used to determine the unknown amounts of HQ in the specified concentrations. The results obtained are promising for the development of the PAAQ-SDS composite film sensors for the electro-analytical determination of phenolic compounds as biologically important materials.

\section{Conclusion}

The present work revealed a conventional approach to the development of a novel voltammetric sensor of catechol-based compounds as biologically important materials. A reversible redox reaction for catechol with increase in the oxidation current and decrease in the peak potential was achieved at the modified electrode compared to the bare electrodes. The performance of the Pt/PAAQ-SDS modified electrode was improved via optimization of the electro-chemical parameters on the electro-catalytic response of catechol. The morphology images illustrated a more porous structure with a nano-particle distribution for the PAAQ-SDS film. The sensor revealed a low observed activation energy $\left(7.05 \mathrm{~kJ} \mathrm{~mol}^{-1}\right)$ and a good stability for the catechol redox reactions. The experimental results obtained showed that the response current increased linearly with increase in catechol in a wide range of concentrations. The detection limit was obtained to be $2.60 \mu \mathrm{M}$ over the concentration range of 10-100 $\mu \mathrm{M}$. The sensor fabricated using the PAAQ-SDS film was also examined to determine the concentration of hydroquinone (HQ). However, the electro-catalytic activity of the modified electrode for catechol was to be larger than HQ. This work can be extended to apply for the qualitative and quantitative determination of other phenolic compounds in biological systems.

\section{Acknowledgment}

The authors wish to thank the Shahrood University of Technology for the financial support of this work.

\section{References}

1. T. Xie, Q. Liu, Y. Shi, Q. Liu, J. Chromatogr. A 2006, 1109, 317-321. http://dx.doi.org/10.1016/j.chroma.2006.01.135

2. A. Lindgren, J. Emnéus, T. Ruzgas, L. Gorton, G. MarkoVarga, Anal. Chim. Acta 1997, 347, 51-62. http://dx.doi.org/10.1016/S0003-2670(97)00126-8

3. S. Nina, J. B. Alexander, R. Zehnder, I. L. Eggen, Environmental Microbiology 2001, 3, 81-91. http://dx.doi.org/10.1046/j.1462-2920.2001.00176.x

4. G. F. Kalf, Crit. Rev. Toxicol. 1987, 18, 141-159. http://dx.doi.org/10.3109/10408448709089859

5. C. Chen, C. Sun, Y. Gao, Electrochim. Acta 2009, 54, 25752580. http://dx.doi.org/10.1016/j.electacta.2008.10.069

6. Y. Zhang, G.-M. Zeng, L. Tang, D.-L. Huang, X.-Y. Jiang, Y.-N. Chen, Biosens. Bioelectron. 2007, 22, 2121-2126. http://dx.doi.org/10.1016/j.bios.2006.09.030

7. S. Timur, N. Pazarlioglu, R. Pilloton, A. Telefoncu, Talanta 2003, 61, 87-93. http://dx.doi.org/10.1016/S0039-9140(03)00237-6

8. E. Nieminen, P. Heikkila, J. Chromatogr. 1986, 360, 271278.

9. K. O. Lupetti, F. R. P. Rocha, O. Fatibello-Filho, Talanta 2004, 62, 463-467. http://dx.doi.org/10.1016/j.talanta.2003.08.018

10. Y-G. Sun, H. Cui, Y-H. Li, X-Q. Lin, Talanta 2000, 53, 661666. http://dx.doi.org/10.1016/S0039-9140(00)00550-6

11. P. Nagaraja, R. A. Vasantha, K. R. Sunitha, J. Pharm. Biomed. Anal. 2001, 25, 417-424. http://dx.doi.org/10.1016/S0731-7085(00)00504-5

12. P. Ramesh, S. Sampath, A. Binderless, Anal. Chem. 2000, 72, 3369-3373. http://dx.doi.org/10.1021/ac000049n

13. A. Ehsani, A. Vaziri-Rad, F. Babaei, H. M. Shiri, Electrochim. Acta 2015, 159, 140-148. http://dx.doi.org/10.1016/j.electacta.2015.01.204

14. A. Chaubey, B. D. Malhotra, Biosens. Bioelectron. 2002, 17 , $441-456$. http://dx.doi.org/10.1016/S0956-5663(01)00313-X

15. S. L. Mu, Biosens. Bioelectron. 2006, 21, 1237-1243. http://dx.doi.org/10.1016/j.bios.2005.05.007

16. S. M. Chen, J. Y. Chen, V. S. Vasantha, Electrochim. Acta 2006, 52, 455-465. http://dx.doi.org/10.1016/j.electacta.2006.05.027

17. R. C. S. Luz, F. S. Damos, A. A. Tanaka, L. T. Kubota, Sens. Actuators B 2006, 114, 1019-1027. http://dx.doi.org/10.1016/j.snb.2005.07.063

18. G. Y. Jin, Y. Z. Zhang, W. X. Cheng, Sens. Actuators B 2005, 107, 528-534. http://dx.doi.org/10.1016/j.snb.2004.11.018

19. A. Ehsani, M. G. Mahjani, M. Jafarian, A. Naeemy, Prog. Org. Coat. 2010, 69, 510-516. 
http://dx.doi.org/10.1016/j.porgcoat.2010.09.007

20. W. A. Badawy, K. M. Ismail, S. S. Medany, Electrochim. Acta 2006, 51, 6353-6360. http://dx.doi.org/10.1016/j.electacta.2006.04.021

21. K. M. Ismail, Z. M. Khlifa, M. A. Azzem, W. A. Badawy, Electrochim. 2002, 47, 1867-1873. http://dx.doi.org/10.1016/S0013-4686(02)00054-3

22. K. Naoi, S. Suematsu, M. Hanada, H. Takenouchi, J. Electrochem. Soc. 2002, 149, 472-477. http://dx.doi.org/10.1149/1.1456920

23. K. Naoi, S. Suematsu, A. Manago, J. Electrochem. Soc. 2000, 147, 420-426. http://dx.doi.org/10.1149/1.1393212

24. B. D. Malhotra, A. Chaubey, S. P. Singh, Anal. Chim. Acta 2006, 578, 59-74.

http://dx.doi.org/10.1016/j.aca.2006.04.055

25. H. Nikoofard, A. Omrani, M. Meftah Niaki, Monatsh. Chem. 2014, 145, 267-273. http://dx.doi.org/10.1007/s00706-013-1090-8

26. H. Nikoofard, F. Masdarolomoor, M. Falahatkar, A. H. Amin, Synth. Met. 2015, 209, 212-219. http://dx.doi.org/10.1016/j.synthmet.2015.07.032

27. D. Myers, Surfaces, Interfaces, and Colloids, VCH, New York, 1991.

28. Y. Kong, S. L. Mu, Chin. J. Chem. 2003, 21, 630-637.
29. M. Hosseini, M. M. Momeni, M. Faraji, J. Appl. Electrochem. 1010, 40, 239-250.

30. J. O. Bockris, A. K. N. Reddy, M. Gamboa-Aldeco, M. E. Gamboa-Aldeco, Modern Electrochemistry, Springer Science \& Business Media, 2001, vol. 2, pp. 1122-1123.

31. S. S. Rosatto, L. T. Kubota, G. O. Neto, Anal. Chim. Acta 1999, 390, 65-72. http://dx.doi.org/10.1016/S0003-2670(99)00168-3

32. E. Dempsey, D. Diamond, A. Collier, Biosens. Bioelectron. 2004, 20, 367-377. http://dx.doi.org/10.1016/j.bios.2004.02.007

33. J. Mocak, A. M. Bond, S. Mitchell, G. Scollary, Pure and Applied Chemistry 1997, 69, 297-328. http://dx.doi.org/10.1351/pac199769020297

34. G. C. Jagetia, K. S. Lakshamy Menon, V. Jain, Toxical. Lett. 2001, 121, 15-20. http://dx.doi.org/10.1016/S0378-4274(00)00290-3

35. P. Yang, Q. Zhu, Y. Chen, F. Wang, J. Appl. Polym. Sci. 2009, 113, 2881-2886. http://dx.doi.org/10.1002/app.30393

36. D. K. Pandey, N. Mishra, P. Singh, Pesticide Biochem. Physiol. 2005, 83, 82-96. http://dx.doi.org/10.1016/j.pestbp.2005.03.013

37. G. Zhao, M. Li, Z. Hu, H. Li, T. Cao, J. Mol. Catal. A 2006, 255, 86-91. http://dx.doi.org/10.1016/j.molcata.2006.03.039

\section{Povzetek}

V delu smo za posredovanje pri prenosu elektronov v elektrokemijski oksidaciji katehola uporabili elektrokemijsko aktivno kompozitno folijo, ki vsebuje okolju prijazni surfaktant natrijev dodecilsulfat (SDS) in poli(1-amino-9,10-antrakinon) (PAAQ). V primerjavi z elektrodo iz čiste platine (Pt) elektrodo Pt / PAAQ-SDS modificirana elektroda izredno zniža maksimalno anodni potencial katehola in hkrati poveča maksimalne tokove. Dobljeni rezultati kažejo, da je aktivacijska energija elektrokemične oksidacije katehola na polimernem film relativno nizka $\left(7,05 \mathrm{~kJ} \mathrm{~mol}^{-1}\right)$. Raziskave morfologije površine modificirane elektrode so pokazale, da ima površina bolj porozno strukturo-verjetno zaradi vključitve anionskega surfaktanta v PAAQ film. Tako modificirana elektroda izkazuje linearni odziv v koncentracijskem območju od 0.01-8.0 mM katehola v raztopini, s spodnjo mejo detekcije pri 2,60 $\mu \mathrm{M}$. 